\title{
In vitro Biosynthesis of the Antitumor Agent Azinomycin B
}

\author{
Chaomin Liu, Gilbert T. Kelly, Coran M. H. Watanabe* \\ Department of Chemistry, Texas A\&M University, College Station, TX 77843 \\ watanabe@mail.chem.tamu.edu
}

\section{SUPPLEMENTAL INFORMATION}

Materials and Methods.

General. Radiolabeled substrates including [2$\left.{ }^{14} \mathrm{C}\right]$ malonylCoA, L- $\left[\mathrm{U}_{-}{ }^{14} \mathrm{C}\right]$ lysine and $\mathrm{L}-\left[\mathrm{U}-{ }^{14} \mathrm{C}\right]$ proline were obtained from Moravek Biochemicals (Brea, CA). All others (DL- $\left[1-{ }^{14} \mathrm{C}\right]$ ornithine, $\left[\mathrm{U}-{ }^{14} \mathrm{C}\right]$ glycine, L-[U$\left.{ }^{14} \mathrm{C}\right]$ valine, DL- $\left[1-{ }^{14} \mathrm{C}\right]$ glutamic acid, L- $\left[\mathrm{U}-{ }^{14} \mathrm{C}\right]$ tyrosine, $\mathrm{L}-\left[\mathrm{U}-{ }^{14} \mathrm{C}\right]$ threonine, $\mathrm{L}-\left[\mathrm{U}-{ }^{14} \mathrm{C}\right]$ ornithine) were acquired from American Radiolabeled Chemicals (St. Louis, MO). TLC plates were purchased from Analtech (Newark, DE). Co-factors (SAM, FAD, and NADPH) and all cell media and buffer components were obtained from Sigma Biochemicals unless otherwise specified. OPTI-Fluor $O$ was purchased from Perkin Elmer (Wellesley, MA). The FAS/PKS inhibitor cerulenin was purchased from Sigma Biochemicals (St. Louis, MO) and all cytochrome P-450 enzyme inhibitors metyrapone, chloramphenicol, and miconazole were available from Aldrich (Milwaukee, WI). Radioactive products were measured on a Beckman LS5910 scintillation counter and the Bead Beater utilized in the preparation of cell-free extracts purchased from Biospec (Bartlesville, OK). Streptomyces sahachiroi (NRRL 2485) was acquired from the American Type Culture Collection (ATCC; Manassas, VA).

Culture Conditions. Streptomyces sahachiroi was initially cultured on GYM plates until sporulation, typically 5-7 days at $28{ }^{\circ} \mathrm{C}$. GYM agar plates contained per liter: glucose monohydrate, $4 \mathrm{~g}$; yeast extract (Difco), $4 \mathrm{~g}$; malt extract (Difco), $10 \mathrm{~g} ; \mathrm{CaCO}_{3}, 2 \mathrm{~g}$; Bacto-agar (Difco), $12 \mathrm{~g}$; and tap water; adjusted to $\mathrm{pH} 6.8$ with $1 \mathrm{M}$ $\mathrm{NaOH}$ prior to sterilization. ${ }^{1} \quad$ A starting culture of Streptomyces sahachiroi in PS5 medium $(100 \mathrm{~mL})$ was prepared by inoculation of a loop full of spores from the GYM plates. PS5 medium was prepared from $5 \mathrm{~g} / \mathrm{L}$ of Pharmamedia (yellow cotton seed flour; Traders Protein; Memphis, TN) and $5 \mathrm{~g} / \mathrm{L}$ of soluble starch, adjusted to a $\mathrm{pH}$ of $7.0{ }^{1}$ Following $24 \mathrm{~h}$ of growth at $30{ }^{\circ} \mathrm{C}, 250 \mathrm{rpm}$, $25 \mathrm{~mL}$ of the starting culture was utilized to inoculate 500 $\mathrm{mL}$ of PS5 in $2 \mathrm{~L}$ baffled Erlenmeyer flasks. The cultures were grown for about $64 \mathrm{~h}\left(30{ }^{\circ} \mathrm{C}, 250 \mathrm{rpm}\right)$. The cells were harvested by centrifugation, the cell pellet frozen in liquid nitrogen (in aliquots), and stored at $-80{ }^{\circ} \mathrm{C}$.

Cell-Free Extract Preparation. The cell-free extract was prepared by combining frozen cells (13-15 g), glass beads (28 g; $0.1 \mathrm{~mm})$, and cell-free extract buffer $(100 \mathrm{mM}$ potassium phosphate, $\mathrm{pH} 7.5 ; 50 \%$ glycerol, $2 \mathrm{mM}$ dithiothreitol, and $1 \mathrm{mM}$ EDTA; $80 \mathrm{~mL} ; 4{ }^{\circ} \mathrm{C}$ ) in a beadbeater equipped with an ice water jacket. The cells were pulverized employing ten $1 \mathrm{~min}$. cycles separated by $1 \mathrm{~min}$. intervals to prevent warming of the protein extract and subsequently centrifuged $(7,660 \mathrm{G}, 15 \mathrm{~min})$ to give the crude cell-free extract.

Enzyme Activity Assays. To each aliquot of the protein extract $(5 \mathrm{~mL})$ was added $1 \mu \mathrm{L}$ of acetyl-CoA $(1 \mathrm{mg} / 1 \mathrm{~mL})$, $80 \mu \mathrm{L}$ of co-factor solution (FAD, $1 \mathrm{mg}$; SAM, $1 \mathrm{mg}$; NADPH, $1 \mathrm{mg}$ in $1 \mathrm{~mL}$ of deionized distilled water), and $0.25 \mu \mathrm{Ci}$ of ${ }^{14} \mathrm{C}$-radiolabeled material. The resulting reaction mixture was incubated at $37{ }^{\circ} \mathrm{C}$ for $24 \mathrm{~h}$. The reactions were vortexed with dichloromethane $(3 \mathrm{~mL})$, organics were transferred to fresh tubes, and evaporated to dryness. The organic residue was resolubilized in a minimal volume of dichloromethane $(60 \mu \mathrm{L})$, and applied to TLC (5: 0.3 ; dichloromethane : methanol; $\mathrm{R}_{\mathrm{f}}=0.25$, naphthoate; $\mathrm{R}_{\mathrm{f}}=$ 0.37, azinomycin $\mathrm{B})$ to which was added unlabeled naphthoate or azinomycin B (isolated from Streptomyces sahachiroi cultures). ${ }^{2,3}$ Samples (TLC spots) with appropriate $\mathrm{R}_{\mathrm{f}}$ values were scraped from the tlc plate, transferred to vials containing OPTI-Fluor $O$ and analyzed by scintillation counting.

HPLC Coinjection Assays. Enzyme activity assays were performed as detailed above. Following extraction and evaporation of the samples to dryness, the organic residue was solubilized in methanol $(100 \mu \mathrm{L})$ to which was added unlabeled naphthoate or azinomycin B and analyzed by HPLC with a Phenomenex C8 column (250 x $4.6 \mathrm{~mm})$, employing a gradient of acetonitrile/water. Conditions are

Table 1. HPLC conditions

\begin{tabular}{ccc}
\hline $\min$ & acetonitrile & water \\
\hline 0 & 10 & 90 \\
1 & 10 & 90 \\
5 & 35 & 65 \\
14 & 95 & 5 \\
15 & 95 & 5 \\
20 & 10 & 90 \\
25 & 10 & 90
\end{tabular}


listed in Table 1. Retention times were $14.9 \mathrm{~min}$. (naphthoate) and $16.2 \mathrm{~min}$. (azinomycin B), respectively. The corresponding peaks were collected, the samples evaporated, transferred to vials containing OPTI-Fluor $O$ and analyzed by scintillation counting.

Protein Inhibition Assays. To each aliquot of the protein extract $(3 \mathrm{~mL})$ was added $1 \mu \mathrm{L}$ of acetyl-CoA $(1$ $\mathrm{mg} / 1 \mathrm{~mL}), 0.25 \mu \mathrm{Ci}$ of $\left[2-{ }^{14} \mathrm{C}\right]$ malonylCoA, $80 \mu \mathrm{L}$ of cofactor solution (FAD, $1 \mathrm{mg}$; SAM, $1 \mathrm{mg}$; NADPH, $1 \mathrm{mg}$ in $1 \mathrm{~mL}$ of deionized distilled water) in addition to $10 \mu \mathrm{M}$ or $100 \mu \mathrm{M}$ inhibitor.

\section{Naphthoic Acid Synthesis.}

\section{1-o-Tolyl-propan-2-ol}

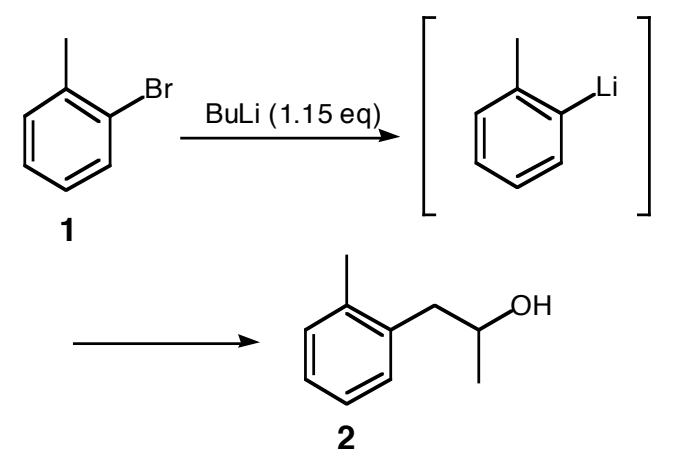

To a solution of 2-Bromotoluene $\mathbf{1}(171 \mathrm{mg}, 1.0 \mathrm{mmol})$ in dry ethyl ether $(5 \mathrm{~mL})$ at $-78^{\circ} \mathrm{C}$, was added butyllithium (0.46 mL, 2.5 $\mathrm{M}$ in hexane) dropwise. Following addition, the cold bath was removed and the reaction mixture allowed to warm to room temperature (RT). After an additional $3 \mathrm{~h}$ of stirring, the reaction mixture was cooled to $-78{ }^{\circ} \mathrm{C}$ and a solution of propylene oxide (0.14 mL in $0.14 \mathrm{~mL}$ of ethyl ether) added dropwise. Stirring was continued at $-78{ }^{\circ} \mathrm{C}$ for an additional hour then allowed to warm to RT. The reaction was allowed to stir overnight and subsequently quenched by the addition of water. The resulting mixture was extracted with ethyl acetate $(10 \mathrm{~mL}$ x 3), dried over $\mathrm{MgSO} 4$ and concentrated. The crude product was purified by flash silica chromatography (230-400 mesh), eluting with EtOAc/hexanes (1:6), to afford 2 as a colorless oil (514 $\mathrm{mg}$, yield 63\%).

\section{1-o-Tolylpropan-2-one}

${ }^{1} \mathrm{H}$ NMR (300 MHz, $\mathrm{CDCl}_{3}$, $\delta: 1.25(\mathrm{~d}, 3 \mathrm{H}, J=6.3 \mathrm{~Hz})$, 2.33 (s, 3H), $2.73(\mathrm{dd}, 1 \mathrm{H}, J=7.8,13.8 \mathrm{~Hz}), 2.77(\mathrm{dd}, 1 \mathrm{H}$, $J=5.4,13.8 \mathrm{~Hz}), 4.00(\mathrm{~m}, 1 \mathrm{H}), 7.15(\mathrm{~m}, 4 \mathrm{H})$.

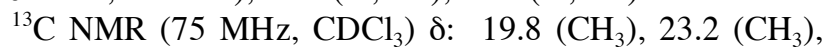
$43.1\left(\mathrm{CH}_{2}\right), 68.1(\mathrm{CH}), 126.2(\mathrm{CH}), 126.8(\mathrm{CH}), 130.3$ (CH), $130.7(\mathrm{CH}), 136.8(\mathrm{C}), 137.0(\mathrm{C})$.

\section{1-o-Tolylpropan-2-one}

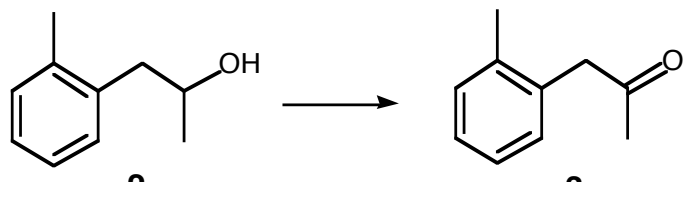

To a solution of 1-o-Tolyl-propan-2-ol 2 (50 mg, $0.33 \mathrm{mmol})$ in ethyl acetate $(2.5 \mathrm{~mL})$, was added 1-hydroxy-1,2benziodoxol-3(1H)-one-1-oxide (IBX), $(280 \mathrm{mg}, 1.0 \mathrm{mmol})^{4,5}$ and the reaction stirred vigorously at $80{ }^{\circ} \mathrm{C}$ for ca. $5 \mathrm{~h}$. The resulting suspension was filtered and the filter cake rinsed three times with ethyl acetate. The combined filtrate was concentrated to afford the crude product, which was then purified by flash silica chromatography [ethyl acetate and hexane (1:6)] to afford 3 as a colorless oil (44.5 $\mathrm{mg}$, yield $91 \%)$.

1-o-Tolyl-propan-2-ol

${ }^{1} \mathrm{H}$ NMR (300 MHz, $\mathrm{CDCl}_{3}$ ) $\delta: 2.15$ (s, 3H), 2.25 (s, 3H), $3.72(\mathrm{~s}, 2 \mathrm{H}), 7.20(\mathrm{~m}, 4 \mathrm{H})$.

${ }^{13} \mathrm{C}$ NMR $\left(75 \mathrm{MHz}, \mathrm{CDCl}_{3}\right) \delta: 19.8\left(\mathrm{CH}_{3}\right), 29.4\left(\mathrm{CH}_{3}\right), 49.3$ $\left(\mathrm{CH}_{2}\right), 126.4(\mathrm{CH}), 127.6(\mathrm{CH}), 130.5(\mathrm{CH}), 130.7(\mathrm{CH})$, $133.3(\mathrm{C}), 137.0(\mathrm{C}), 206.6(\mathrm{C})$.

\section{2-Hydroxy-4-oxo-5-o-tolyl-pent-2-enoic acid ethyl ester}

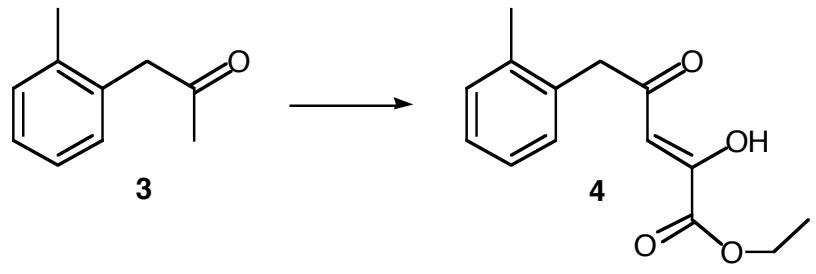

A solution of 1-o-Tolylpropan-2-one 3 (1.9 g, $12.8 \mathrm{mmol})$ in diethyl ether $(60 \mathrm{~mL})$, was cooled to $0{ }^{\circ} \mathrm{C}$ to which a solution of EtONa (Na $294 \mathrm{mg}, 12.8 \mathrm{mmol}$ in $5 \mathrm{~mL}$ of ethanol) was added dropwise. The reaction was allowed to stir for about 30 min. (at $0{ }^{\circ} \mathrm{C}$ ), followed by the dropwise addition of diethyl oxalate $(1.87 \mathrm{~g}, 12.8 \mathrm{mmol})$. The reaction mixture was subsequently stirred at RT for $24 \mathrm{~h}$. The resulting pale yellow solid product, was collected by filtration and washed with cold ethyl ether giving the desired product $\mathbf{4}$ as its sodium enolate in $85 \%$ yield $(2.9 \mathrm{~g})$. The enolate was directly utilized in the next step without further purification.

sodium enolate salt

${ }^{1} \mathrm{H}$ NMR (300 MHz, $\mathrm{CDCl}_{3}$, $)$ : $1.15(\mathrm{t}, 3 \mathrm{H}, J=7.2 \mathrm{~Hz}), 2.11$ (s, 3H), 3.38 (s, 2H), 3.97 (q, 2H, J = $7.2 \mathrm{~Hz}), 5.76(\mathrm{~s}, 1 \mathrm{H})$, 6.97 7.01 (m, 4H).

\section{3-Hydroxy-5-methyl-naphthalene-1-carboxylic acid ethyl ester}<smiles>CCOC(=O)/C(O)=C/C(=O)Cc1ccccc1C</smiles>

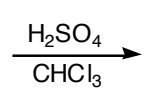<smiles>CCOC(=O)c1cc(O)cc2c(C)cccc12</smiles>

Concentrated sulfuric acid $(0.5 \mathrm{~mL})$ was added slowly to a chilled solution of starting material $4\left(0{ }^{\circ} \mathrm{C}\right)$, sodium enolate $(65.7 \mathrm{mg}, 0.24 \mathrm{mmol})$ in chloroform $(9 \mathrm{~mL})$, with vigorous 
stirring. Following addition, the reaction mixture was stirred continuously at $0{ }^{\circ} \mathrm{C}$ for about $20 \mathrm{~min}$. The reaction was then warmed to RT and stirred for an additional 30 min. The reaction mixture was poured into ground ice (25 $\mathrm{mL})$, extracted with methylene chloride $(25 \mathrm{~mL} \times 4)$, dried over $\mathrm{MgSO}_{4}$ and concentrated in vacuo. The organic residue was

subsequently purified by flash silica chromatography (1:5 EtOAc/Hexanes) to generate the desired product 3hydroxy-5-methyl-naphthalene-1-caboxylic acid ethyl ester 5 (38.7 $\mathrm{mg}, 71 \%$ yield).

3-hydroxy-5-methyl-naphthalene-1-caboxylic acid ethyl ester

${ }^{1} \mathrm{H}$ NMR (300 MHz, $\left.\mathrm{CDCl}_{3}\right) \delta: 1.48(\mathrm{t}, 3 \mathrm{H}, J=7.2 \mathrm{~Hz})$, $2.63(\mathrm{~s}, 3 \mathrm{H}), 4.50(\mathrm{q}, 2 \mathrm{H}, J=7.2 \mathrm{~Hz}), 5.81$ (bs, $1 \mathrm{H}, \mathrm{OH})$, 7.34-7.38 (m, 2H), $7.54(\mathrm{dd}, 1 \mathrm{H}, J=0.75,2.7 \mathrm{~Hz}), 7.81$ $(\mathrm{d}, 1 \mathrm{H}, J=2.7 \mathrm{~Hz}), 8.61(\mathrm{~m}, 1 \mathrm{H})$.

${ }^{13} \mathrm{C}$ NMR $\left(75 \mathrm{MHz}, \mathrm{CDCl}_{3}\right)$ d: $14.6\left(\mathrm{CH}_{3}\right), 20.2\left(\mathrm{CH}_{3}\right)$, $61.7\left(\mathrm{CH}_{2}\right), 111.7(\mathrm{CH}), 121.1(\mathrm{CH}), 124.1(\mathrm{CH}), 125.1$ $(\mathrm{CH}), 127.1(\mathrm{C}), 127.8(\mathrm{CH}), 130.2(\mathrm{C}), 133.2(\mathrm{C}), 134.8$ (C), $152.2(\mathrm{C}), 168.0(\mathrm{C})$.

\section{3-Methoxy-5-methyl-naphthalene-1-carboxylic acid}

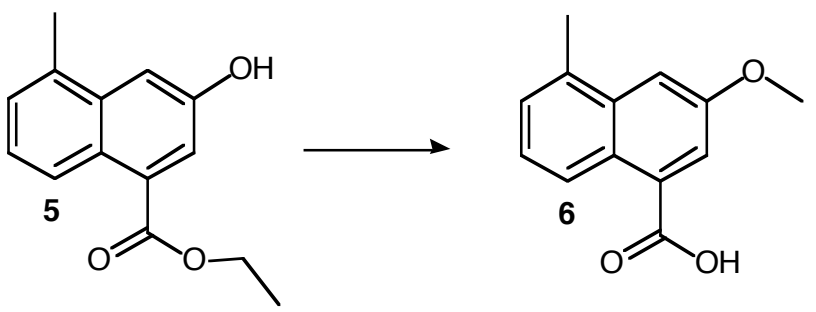

To a solution of 3-Hydroxy-5-methyl-naphthalene-1caboxylic acid ethyl ester 5 (101 mg, $1.0 \mathrm{mmol})$ and dimethyl sulfate $(142.3 \mathrm{mg}, 1.1 \mathrm{mmol})$ in $0.5 \mathrm{~mL}$ of dioxane, was added a $25 \%$ solution of aqueous sodium hydroxide $(1.5 \mathrm{~mL})$. After stirring at RT for $30 \mathrm{~min}$, the mixture was heated to $\sim 100{ }^{\circ} \mathrm{C}$ for $6 \mathrm{~h}$ and cooled to RT. The resulting basic mixture was extracted with dichloromethane ( $3 \mathrm{~mL} \times 2)$. The aqueous phase was acidified to $\mathrm{pH} 5$ by addition of concentrated hydrochloride and extracted with ethyl acetate $(5 \mathrm{~mL} \times 3)$. The organics were dried over $\mathrm{MgSO}_{4}$ and concentrated in vacuo to afford the final product $\mathbf{6}$ as a pale white solid in quantitative yield.

${ }^{1} \mathrm{H}$ NMR (300 MHz, $\left.\mathrm{CDCl}_{3}\right) 2.69$ (s, 3H), 3.99 (s, 3H), 7.38-7.43 (m, 2H), $7.54(\mathrm{~d}, 1 \mathrm{H}, J=2.4 \mathrm{~Hz}), 8.05(\mathrm{~d}, 1 \mathrm{H}, J$ $=2.4 \mathrm{~Hz}), 8.30(\mathrm{~m}, 1 \mathrm{H})$

${ }^{13} \mathrm{C}$ NMR $\left(75 \mathrm{MHz}, \mathrm{CDCl}_{3}\right) 20.2\left(\mathrm{CH}_{3}\right), 55.5\left(\mathrm{CH}_{3}\right), 109.3$ $(\mathrm{CH}), 122.8(\mathrm{CH}), 123.9(\mathrm{CH}), 125.2(\mathrm{CH}), 127.1(\mathrm{C})$, $127.6(\mathrm{CH}), 127.8(\mathrm{C}), 133.2(\mathrm{C}), 134.4(\mathrm{C}), 155.8(\mathrm{C})$, $172.9(\mathrm{C})$.

\section{References}

(1) Corre, C.; Lowden, P. A. S. Chem. Commun. 2004, 990 .
(2) Hata, T.; Koga, F.; Sano, Y.; Kanamori, K.;Matsumae, A.; Sugawara, R.; Hoshi, T.; Shima, T. J. Antibiot. 1954. SER. A, 107.

(3) Kouichi, Y.; Nagaoka, K.; Nakashima, T. Chem. Pharm. Bull. 1986. 34, 4554.

(4) Dess, D. B.; Martin, C. J. Am. Chem. Soc. 1991. $113,7277$.

(5) More, J. D.; Finney, N. S. Org. Lett. 2002. 4, 3001. 